FACTA UNIVERSITATIS

Series: Economics and Organization Vol. 18, No 4, Special Issue, 2021, pp. 325 - 339

https://doi.org/10.22190/FUEO210628023T

Original Scientific Paper

\title{
BANKS' CORPORATE SOCIAL RESPONSIBILITY (CSR) DISCLOSURE AND THEIR ROLE IN THE BETTERMENT OF SOCIETY IN THE REPUBLIC OF NORTH MACEDONIA
}

\author{
UDC 005.35(497.7)
}

\section{Marina Trpeska, Todor Tocev, Ivan Dionisijev, Bojan Malchev}

Ss. Cyril and Methodius University in Skopje, Faculty of Economics - Skopje, Republic of North Macedonia

$\begin{array}{ll}\text { ORCID iD: } & \text { Marina Trpeska } \\ \text { Todor Tocev } & \text { (b) https://orcid.org/0000-0001-9996-7286 } \\ \text { Ivan Dionisijev } & \text { (b) https://orcid.org/0000-0001-7656-1240 } \\ \text { Bojan Malchev } & \text { (b) https://orcid.org/0000-0001-5986-3343 } \\ & \end{array}$

\begin{abstract}
Corporate Social Responsibility (CSR) is of great importance for companies and other stakeholders, which obliges the companies to establish a way of management that will simultaneously take care of the environmental, social, and ethical aspects of factors. If corporate responsibility is the guiding factor for companies, they can easily gain a competitive advantage over others. This paper researches how the banks in the Republic of North Macedonia report on CSR and in what report format CSR data is published. The research is based on the method of content analysis and statistical analysis to determine whether the size and profit of banks affect the CSR Reporting. The sample included in the research is 14 banks that the National Bank of the Republic of North Macedonia has granted a license to operate. The results of this research show that the size of banks has a positive effect on CSR reporting, while on the other hand, profit does not affect it.
\end{abstract}

Keywords: CSR, Disclosure, Banks, North Macedonia

JEL Classification: G21, M14

Received June 28, 2021 / Accepted July 15, 2021

Corresponding author: Marina Trpeska

Ss Cyril and Methodius University, Faculty of Economics - Skopje, Department of Accounting and Auditing, bul.

Goce Delcev 9V, 1000 Skopje, Republic of North Macedonia |E-mail: marina.serafimoska@eccf.ukim.edu.mk

(๑) 2021 by University of Niš, Serbia | Creative Commons Licence: CC BY-NC-ND 


\section{INTRODUCTION}

Corporate Social Responsibility (CSR) reports refer to a company's systematic disclosure of information about its social performance. The term social performance has a broad understanding and refers to social, environmental and governance issues that are not generally included in financial performance indicators. Compared to management accounting, CSR reporting is primarily directed at external stakeholders, such as clients, investors, and the public. In the absence of mandatory formal rules, CSR reports differ greatly in form (design, means of distribution, reporting frequency, etc.) and content (scope, quality, etc.) (Schreck, 2013). In recent years, the scope of voluntary CSR reports has been expanded in response to demands that companies should be more responsible for their actions (KPMG, 2020). A Corporate Social Responsibility or Sustainability Report is periodic report (usually annual report) or more generally part of the company's financial/annual reports, aimed at sharing its philanthropy, corporate social responsibility actions and results. The report synthesizes and discloses the information that the organization decides to convey about its commitments and actions in the social and environmental fields. By doing so, the organization allows stakeholders to understand how they integrate the principles of sustainability into their daily operations (Youmatter, 2020). Regardless of the precise definition, with growing attention to firms' CSR strategies, interest in how firms account for, and report on, their CSR activities have also increased, and social responsibility is considered essential to the long-term survival of the company (Simms, 2002). Today, many industry different companies across many countries have introduced some form of social performance disclosure. Banks are increasingly involved in financing activities aimed at sustainable development (Scholtens, 2009). The issue of voluntary and mandatory CSR disclosure has been debated for several years. Proponents of voluntary disclosure note that corporate social responsibility reporting has increased in the last decade and believe that, for various reasons, companies have an incentive to disclose social and environmental behaviors without being forced (Jain et al., 2015).

Guided by the following issues and current topic in the increasingly complex environment and the necessary role of companies in society, the main objective of this paper is to measure the level of CSR reporting of actively operating banks in North Macedonia, the way they report and analysis of indicators that have a potential impact on the level of social responsibility, such as the size of the bank through the prism of total assets and profits as individual and related variables. Method of content analysis and statistical testing are taken into account as an approach to determine the situation and CSR disclosure in all banks that operate on the Macedonian market.

The paper first summarizes the relevant literature and current data related to social responsibility reporting, followed by a specific presentation on the situation of the CSR in North Macedonia. The conducted research is explained through the used methodology of data collection and statistical testing, the obtained results and appropriate interpretation of the same. In the further part of the paper, all the limitations and suggestions for further research are mentioned, as well as a complete conclusion based on the literature and the conducted research. 


\section{THEORETICAL FRAMEWORK}

Banks play an important role in the modern economy of society, where a well-functioning financial system is essential. As an intermediary, banks provide a wide range of financing and savings solutions, risk management and payment services for various clients, and advise them, thus playing a fundamental role in society. The importance of banks can be also seen in the fact that they are considered the lifeblood of the modern economy.

Although banks do not create wealth, their essential activities promote the process of wealth production, exchange, and distribution (Farooq, 2020). Compared with the practices of the 21st century, management that does not meet the needs and expectations of community stakeholders will not be competitive. Corporate social performance (CSP) is as important as corporate financial performance (CFP) (Baird et al., 2012). Banks have a unique way of impacting on society, that is, they can engage themselves in CSR activities or they can influence other companies by financing the latter's projects with social, ethical, and environmental issues (Scholtens, 2006). Therefore, banks can also influence sustainable development through their environmental actions and impacts, and help limit or conversely strengthen the socio-economic problems that plague modern society (Lukasz \& Justyna, 2019). The growth in reporting suggests that the issue of CSR is receiving more attention from the firms and that the number of reportable policy initiatives has increased. The main purpose of a sustainability report or CSR is to increase the transparency of organizational activities. There are two goals (Youmatter, 2020): on the one hand, the CSR report aims to allow companies to measure the environmental, social and economic impact of their activities (the famous triple-bottom-line). In this way, companies can obtain accurate and enlightening data which will help them improve their processes and have a more positive impact on society and the world. On the other hand, a CSR or sustainability report also allows companies to externally communicate their sustainability and corporate social responsibility goals to their stakeholders. Banks are more likely to present CR information in their annual financial report than companies in any other sector (KPMG, 2016). Banks and other financial services providers play an important role because banks are not only recipients of socially responsible investments, but also providers. Obviously, banks can benefit from applying some of the most basic concepts of CSR to their own human resource policies, and community engagement policies, but the involvement of banks in CSR reporting is neither overwhelming nor uniform in all countries. Some countries (e.g. France) have made CSR and its reporting mandatory, while in other countries, banks have carried out more or less CSR activities on a voluntary basis (Khan, Halabi, \& Samy, 2009). Companies that demonstrate a sense of social responsibility get specific benefits. These benefits according to Adams \& Ambika (2004) include: better recruitment and retention of employees, improved internal decision making and cost savings, improved corporate image and relations with stakeholders, improved financial returns, etc. GRI (Global Reporting Initiative) is an independent international organization that provides companies and other organizations with a universal language to communicate these impacts through the most widely used sustainability reporting standards in the world - the GRI Standards, thus helping companies and other organizations to take responsibility for their impacts 


\section{LITERATURE REVIEW}

According to Carroll (1979), CSR is "economic, legal, ethical and discretionary expectations that society has of organizations at a given point of time". Matuszak et al. (2019) based on this definition and drawing attention to the fact that society has defined expectations for company operations and wants to know about such activities i.e. what companies contribute and do for the good of society. Even though a common traditional belief is that organizations need only to prepare financial reports that are required under the laws, accounting standards, or stack-exchange listing rules, ACCA (2015) suggests and indicates the importance of the environmental report, which is the production of narrative and numerical information on an organization's environmental impact within the reporting period.

Summarizing all relevant concepts, Garriga \& Melé (2004) and Rogošić (2014) classify the main theories and related approaches of CSR into four categories:

1. Instrumental theories, where the organizations are only seen as a profitable business, and social activities are only seen as a means for achieving financial benefits;

2. Political theories, through which corporations, using social responsibility, gain power and political status in society;

3. Integrative theories, where the company focuses on satisfying social needs; and

4. Ethical theories, which are based on philanthropy, moral and ethical responsibilities of companies to society.

PwC (2013) revealed a document referring to "The rise of corporate social responsibility" that describes the SCR report as a "tool for sustainable development in the Middle East and suggests to the companies that greater access to more contextual and non-financial information increases the confidence of securities analysts when preparing recommendations for the buying/selling of companies' shares, but also increases the public trust and confidence".

The KPMG (2013 \& 2015) view of corporate responsibility is that many companies no longer see it as an ethical issue, but rather as a core business risk, raising the question: What is the potential financial impact of these risks? And what steps does the company take to alleviate it.

According to the Hauser Institute for Civil Society (2015), with increasing social pressure to strengthen financial and corporate market regulation and transparency, corporate social responsibility reporting has increasingly become an area of concern.

This growth in reporting practice and interest from investors illustrates that businesses are responding to both increased regulation and cultural shifts in how individuals view the operation of corporations and the financial system at large.

From the KPMG (2020) Survey of Sustainability Reporting it can be seen that (96\%), or almost all of the 250 largest companies in the world (the G250) reported on their sustainability performance. For N100 $-5,200$ companies comprised of the 100 largest companies in 52 countries - $80 \%$ do report.

GRI remains the most widely used reporting standard or framework, utilized by approximately two-thirds of N100 respondents and approximately three-quarters of G250 respondents. The application of the GRI Standards (launched at the end of 2016) has increased significantly since 2017 and has continued to grow in recent years.

One of the first comprehensive studies on the status and level of CSR in North Macedonia was published in 2007 from UNDP, called the Baseline study. This study refers to the level of acceptance and awareness of CSR in North Macedonia and reveals 
that the business community has not yet fully understood and implemented it, due to the lack of relevant knowledge and practical tools (Baseline Study).

In 2008, North Macedonia became the third EU country to adopt a national CSR Agenda after Denmark and Lithuania (Stamenkova, 2011). The CSR Agenda is a comprehensive governmental plan that addresses CSR in North Macedonia. It is very similar to the Danish Action Plan, but there is an important difference between the two that is worth mentioning. According to the Macedonian document, the concept of CSR includes compliance with legal obligations, minimizing or eliminating the company's negative impact on society and increasing the positive impact. On the other hand, the Danish Action Plan limits the definition of CSR to voluntary initiatives (Stamenkova, 2011).

Rogošić (2014) in his research paper confirmed that there is a positive correlation between asset value and profits and the CSR reporting levels of the banks from Croatia, Bosnia and Herzegovina, and Montenegro by using statistical regression analysis where the level of CSR reporting was set as a dependent variable.

Matuszak et al. (2019) through content analysis and panel data analysis of annual reports and CSR reports of the banks operating in Poland for the period between 2008 2015 , obtained results from testing several hypotheses which indicates that there are statistically significant differences in the level of CSR disclosures between banks with a different ownership structure; compared to unlisted companies, the public listing has a positive impact on corporate social responsibility; almost all variables related to the size, management board and foreign board members are relevant and have a significant positive effect on CSR disclosure.

Levkov \& Palamidovska-Sterjadovska (2019) used a sample for the research of 102 banks, actively operating in the Western Balkan Countries for a three -year- period (2015 - 2017) and the results reveal that in North Macedonia, foreign and local banks attained an equal average score of CSR reporting, while in Serbia, Kosovo, Bosnia Herzegovina, and Montenegro, foreign banks have attained a higher score, i.e. higher level of CSR disclosure. The results from conducted regression analysis show that the size of the bank (total assets) is a moderate predictor of CSR reporting. Overall, their study shows that there are inconsistencies in disclosure of CSR initiatives on different markets, considering Western Balkan Countries.

The method of content analysis and regression analysis with the size bank (total assets) and the profitability as an independent variable were used in previous studies (Branco and Rodrigues, (2006); Hinson, Boateng \& Madichie, (2010); Khan, (2010); Nyarku and Hinson, (2017); Matuszak et al., (2019); Levkov \& Palamidovska-Sterjadovska, (2019)) to determine the disclosure of social responsibility in annual reports and banks' websites. In order to avoid the problem that arises from covering only descriptive data (Jiang et al., (2011), Nyarku \& Hinson (2017)) and guided by the latest research conducted on the Macedonian banking sector together with the countries of the Western Balkan (Levkov \& PalamidovskaSterjadovska, 2019), which was also based on research from Matuszak et al. (2019) and previous studies (Fatma \& Rahman, (2014); Kılıç, M., \& Uyar, A. (2014); Nyarku \& Hinson, (2017)), we used a binary scoring method of the CSR disclosures recorded in 1) annual reports, 2) financial reports and/or 3) web (online) content as a separate CSR heading. Following the same studies and due to the similar concept and social status of the banks, we used the already recognized and defined four key stakeholder groups in this sector: (1) environment, (2) employees, (3) customers, and (4) community. According to Hinson et al., (2010) environment related activities are the company's environmental concern, loan 
and investment policies, energy conservation in business operations, and other supporting activities and calls for a cleaner and ecological environment; employees - working environment, employee health and safety, team buildings and trainings and employee remuneration; customers - product and service quality, customer complaints/satisfaction and services provided to customers with physical disabilities; community - charitable donations and activities, support for education and sports sponsoring or recreational projects.

As Achua (2008) states that banks have an important role in financial stability and economic development in countries, they must take social responsibility in order to build a reputation and attract investors, expand their customer base, attract qualified employees and earn the trust of the public.

Taking social responsibility is becoming the focus of banks' attention because their reputation depends on their CSR policies and plans (Dorasamy, 2013).

Consumers and governments are pushing business organizations to become more involved in social responsibility initiatives, which is why businesses today are working hard to become more involved in CSR initiatives and to publicly promote their CSR activities through their websites (Levkov \& Palamidovska-Sterjadovska, 2019).

\section{CSR REPORTING IN MACEDONIAN BANKING INDUSTRY}

In North Macedonia, corporate social responsibility (CSR) was first introduced as a concept in 2002 through the activities of the World Bank Institute of the World Bank Group, UNDP, and USAID (Stamenkova, 2011). In December 2007, the Ministry of Economy of North Macedonia established the National Coordinating Body for Corporate Social Responsibility (NCB CSR) as a permanent working group within the Economic and Social Council of the Government of North Macedonia. NCB CSR is a crosssectorial body responsible for developing multiple dialogues and identifying joint actions for the promotion and implementation of CSR. In June 2008, as part of the NCB's CSR work plan, the "National Agenda for Corporate Social Responsibility" was prepared. The agenda was adopted by the Government in October 2008. The goals of the Agenda are to raise CSR awareness, develop capacities and competencies to help establish CSR and provide a favorable CSR environment.

The banking sector plays a vital role in the Macedonian economy and can undoubtedly contribute to economic growth and social welfare. Historically, banks have been considered as public trust institutions, so people have expectations about their highly professional and socially responsible behaviors (Molyneux et al., 2014). The important role of the banks has been increased through CSR initiatives, including environmental protection and sustainability, community participation, occupational health and safety, employee development and training, bank products for marginalized groups, etc. (Levkov \& Palamidovska-Sterjadovska, 2019).

According to the latest reports of the National Bank of North Macedonia including 31 December 2020, fourteen banks have actively been working, and five out of them count as large banks, six are medium-sized banks, and three are small banks. Compared to the previous two years 2018 and 2017 which are taken into account for the research, there is a change in the number of medium-sized banks, due to the closure of Eurostandard Bank. Due to the small market share of a large number of banks, the Macedonian banking market qualifies as a non-competitive environment (Filipovska, 2019). We focus on the CSR reporting activity of all licensed banks, but the main focus and discussion are based on large banks, because almost all CSR reports are issued individually or as part of the annual report. 
In the Macedonian environment where "the rule of law is still not to be taken for granted" (Stamenkova, 2011), it shows that CSR is still not legally required, but it is still a vague concept, frequently equated with donations, sponsorships, and philanthropy, usually perceived as an obligation for large and profitable companies only.

Banks in North Macedonia, following the global trend of the manner of reporting on social responsibility, disclose CSR information mainly through their websites, as well as in the annual reports where the descriptive part lists the social activities, but it is worth to be noted that neither are they listed and compiled in the financial statements nor are CSR financial expenditure data available.

\section{RESEARCH METHODOLOGY}

In this research we applied content analysis methods to measure the CSR reporting activities of all licensed banks in North Macedonia, focusing on the large banks, which are actively operating until December 2020, and regression analysis on asset values and CSR reporting levels. The population and the sample used for this research is composed of 14 banks - all banks actively operating in North Macedonia.

The data about granted licenses were obtained from the official website of the National Bank of the Republic of North Macedonia. All banks operating on the Macedonian market have an official accessible website and published financial statements and annual reports from which CSR data were obtained.

As it was mentioned before, to overcome the limitation of using only descriptive data, we use a binary scoring approach of the CSR disclosures. The scoring was conducted depending on whether CSR data are available at all (whether published in financial statements, annual reports, or as a separate section of a website) and whether the four key stakeholders in the banking sector are covered, namely: (1) environment, (2) employees, (3) customers and (4) community.

To be able to provide the essential data, i.e. CSR data, we followed the procedure of searching the Banks' financial statements and annual reports, independent CSR reports, and website through all headings on the Web and links that lead to data on corporate social responsibility of the bank.

Table 1 summarizes the research methodology for how points are generated and how many total points a bank can earn.

Table 1 Research methodology for CSR points

\begin{tabular}{lcc}
\hline Description & $\begin{array}{c}\text { "Yes" } \\
\text { Max points }\end{array}$ & $\begin{array}{c}\text { "No" } \\
\text { Min points }\end{array}$ \\
\hline 1. Are CSR data available? & 1 & 0 \\
2. CSR reporting referring to the environment? & 1 & 0 \\
3. CSR reporting referring to employees? & 1 & 0 \\
4. CSR reporting referring to customers? & 1 & 0 \\
5. CSR reporting referring to the community? & 1 & 0 \\
\hline Total points per bank for 1 year & 5 & 0 \\
Total points for the observed period of 3 years (2017-2019) & $\mathbf{1 5}$ & $\mathbf{0}$ \\
\hline
\end{tabular}

Source: Authors' calculation 
In addition to the content analysis and summarized relevant literature from already conducted research, the following hypotheses are set:

$H_{l}=$ The size of a bank has a positive impact on the level of CSR reporting done by banks. $\mathrm{H}_{2}=$ The bank's profit has a positive impact on the level of CSR reporting done by banks.

Due to the current situation caused by the pandemic COVID-19, many changes are taking place in both the world and the domestic market. Large and successful companies are expected to contribute to the easier overcoming of the crisis and make a positive contribution to society. According to media reports and information on social networks, banks in North Macedonia are one of the largest donors, which is an important issue worthy studying and discussing. Due to still unpublished annual reports by the bank, there is a restriction on access to annual data for CSR activities in the period of COVID19 and therefore it will be processed only descriptively.

For testing the hypotheses, the appropriate indicators are taken into account, i.e. for the Bank Size in this research, the value of the average total assets for 2017, 2018, and 2019 are used $\left(\mathrm{H}_{1}\right)$, which are presented in the Balance Sheet of the banks and the measurement of the Bank Profit is de facto the average absolute amount of the profit for 2017, 2018 and $2019\left(\mathrm{H}_{2}\right)$, which are stated in the Income Statement of the banks.

This research uses a quantitative research method. The processing of the collected data was done through several statistical methods and tests, using SPSS software. The model is formulated as follows:

$$
\mathbf{Y}=\beta_{0}+\beta_{1} \mathbf{X}_{1}+\beta_{2} \mathbf{X}_{2}+\varepsilon
$$

where: $\mathbf{Y}=$ CSR Reporting; $\mathbf{X}_{1}=$ Bank Size; $\mathbf{X}_{2}=$ Bank Profit; $\boldsymbol{\varepsilon}=$ random error

The analysis of the collected data includes several statistical tests, as follows: 1. Data normality testing to determine if data are normally distributed for decision making and conclusions. This test involves preparing a histogram of the dependent variable to see if the residual is skewed and a simple Kolmogorov-Smirnov test is performed. If the significance value of the test is greater than 0.05 then it means that the data are normally distributed.

2. Multicollinearity test to determine the relationship between the independent variables. Multicollinearity can be detected by the Variance Inflation Factor (VIF). If the value of Centered VIF is less than 10, then it means that there is no multicollinearity.

3. Regression testing to see if the change in variable $\mathrm{Y}$ can be explained by variable $\mathrm{X}$. In this test, we use the coefficient $R^{2}$ ( $R$ square).

\section{RESULTS AND DISCUSSION}

From conducted content analysis for the level of the banks' reporting on social responsibility, Table 2 presents the total CSR score according to bank size. 
Banks' Corporate Social Responsabilty (CSR) Disclosure and Their Role in the Betterment of Society ... 333

Table 2 CSR reporting in banking sector according to their size

\begin{tabular}{|c|c|c|c|c|c|c|c|}
\hline Banks & $\begin{array}{c}\text { Number of } \\
\text { banks }\end{array}$ & $\begin{array}{l}\text { Total } \\
\text { CSR } \\
\text { points }\end{array}$ & $\begin{array}{l}\text { Average } \\
\text { CSR score }\end{array}$ & $\begin{array}{c}\text { Max } \\
\text { points }\end{array}$ & $\begin{array}{l}\text { Min } \\
\text { points }\end{array}$ & $\begin{array}{l}\text { Number of } \\
\text { banks with } \\
\text { max points }\end{array}$ & $\begin{array}{l}\text { Number of } \\
\text { banks with } \\
\text { min points }\end{array}$ \\
\hline Large sized banks & 5 & 65 & 13 & 15 & 11 & 2 & 0 \\
\hline Medium sized banks & 6 & 21 & 3,5 & 9 & 0 & 1 & 3 \\
\hline Small sized banks & 3 & 12 & 4 & 6 & 0 & 2 & 1 \\
\hline Total & 14 & & & & & $2^{*}$ & 4 \\
\hline
\end{tabular}

Only two out of fourteen banks have the maximum number of points (15) for CSR reporting which are from the large banks' group, while a total of four banks have a score of 0 points.

The CSR activity report score used in this paper ranks banks according to the indicators in Table 3.

Table 3 CSR disclosure of banks in North Macedonia

\begin{tabular}{lccrrr}
\hline \multicolumn{1}{c}{ Banks } & $\begin{array}{c}\text { CSR data } \\
\text { availability }\end{array}$ & Environment & Employees & Customers & Community \\
\hline Large sized banks & 15 & 10 & 15 & 10 & 15 \\
Medium sized banks & 9 & 6 & 0 & 0 & 6 \\
Small sized banks & 6 & 0 & 0 & 0 & 6 \\
\hline Total & 30 & 16 & 15 & 10 & 27 \\
\hline \multicolumn{7}{c}{ Source: Authors' calculation }
\end{tabular}

From the total maximum of 42 points that banks can achieve if they have published data about CSR for the period of three years (2017-2019), it can be seen that the total number of achieved points is 30 , or $71 \%$.

According to the four indicators i.e. stakeholders as an element of whether they are included in the reporting, the following data were obtained: Environmental 16 points (38\%), Employees 15 points (36\%), Customers 10 points (24\%), and Community 27 points $(65 \%)$. It can be concluded that most of the banks are active in the activities intended for the community.

Table 4 summarizes the results regarding the instruments used by banks in the disclosure of social responsibility information.

Table 4 Instruments used by banks to conduct CSR data

\begin{tabular}{lccc}
\hline Banks & $\begin{array}{c}\text { Independent } \\
\text { report }\end{array}$ & $\begin{array}{c}\text { Part of annual } \\
\text { or financial report }\end{array}$ & $\begin{array}{c}\text { Web CSR } \\
\text { link/heading }\end{array}$ \\
\hline Large-sized banks & 1 & 4 & $/$ \\
Medium-sized banks & $/$ & 2 & 1 \\
Small-sized banks & $/$ & 2 & $/$ \\
\hline Total & 1 & 8 & 1 \\
\hline
\end{tabular}

Source: Authors' calculation 
Of all banks that actively operate in North Macedonia, ten out of a total of fourteen banks $(71 \%)$ report on social activities. Only one bank from the group of large-sized banks has an independent report for CSR activities, which indicates that banks in North Macedonia are not inclined to prepare a separate report exclusively for the CSR. Most banks that report on CSR summarize the data as part of an annual or financial report.

The results obtained from statistical data processing using SPSS software for testing the hypotheses of whether Bank Size and Profit affect the CSR reporting are presented as follows:

- Residual normality test using One-Sample Kolmogorov-Smirnov Test

This test is done to determine if the sample in the research is normally distributed or not, by testing the normality of the residuals. The first test is shown in histogram 1 and table 2 below.

Histogram 1 Data distribution

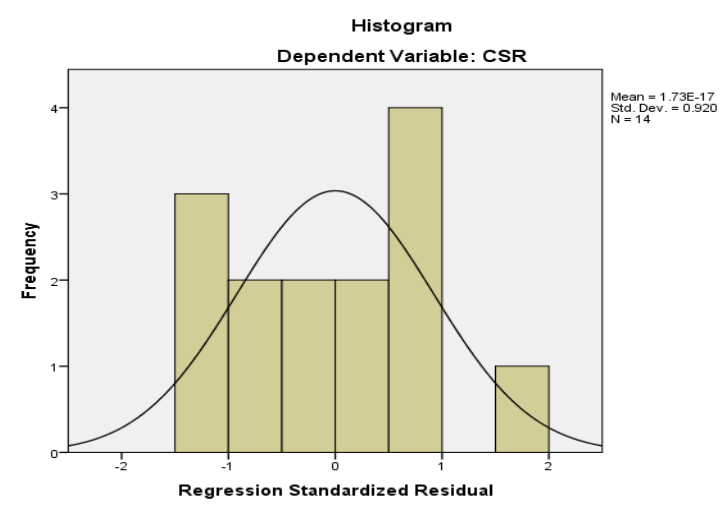

Source: Authors' calculation

Table 5 One-Sample Kolmogorov-Smirnov Test

\begin{tabular}{llccc}
\hline & & CSR & Profit & Size \\
\hline $\mathrm{N}$ & & 14 & 14 & 14 \\
Normal Parameters & Mean & 7.00 & 559966.5000 & 35321.5000 \\
& Std. Deviation & 5.533 & 807350.53484 & 36009.72815 \\
& Absolute & .183 & .298 & .233 \\
Most Extreme Differences & Positive & .183 & .298 & .233 \\
& Negative & -.143 & -.246 & -.182 \\
Kolmogorov-Smirnov Z & & .684 & 1.116 & .870 \\
Asymp. Sig. (2-tailed) & & .738 & .166 & .436 \\
\hline
\end{tabular}

a. Test distribution is Normal.

b. Calculated from data.

Source: Authors' calculation

Histogram 1 shows that the residuals are normally distributed, it is not skewed either left or right. From Table 5, it can also be concluded that the obtained values of 0.738, 0.166 and 0.436 (Asymp. sig. 2-tailed) respectively are greater than 0.05 , which means that the residuals have a normal distribution. This data can be used in the further research process. 
- Multicollinearity test

Table 6 shows the Variance Inflation Factor (VIF) values for the two independent variables (size and profit) and all values are less than 10. This means that there is no multicollinearity between the two variables.

Table 6 Multicollinearity test

\section{Coefficients}

\begin{tabular}{|c|c|c|c|c|c|c|c|c|c|}
\hline & \multirow[b]{2}{*}{ Model } & \multicolumn{2}{|c|}{$\begin{array}{l}\text { Unstandardized } \\
\text { Coefficients }\end{array}$} & \multirow{2}{*}{$\begin{array}{c}\begin{array}{c}\text { Standardized } \\
\text { Coefficients }\end{array} \\
\text { Beta }\end{array}$} & \multicolumn{3}{|c|}{ Correlations } & \multicolumn{2}{|c|}{$\begin{array}{l}\text { Collinearity } \\
\text { Statistics }\end{array}$} \\
\hline & & B & $\begin{array}{l}\text { Std. } \\
\text { Error }\end{array}$ & & $\begin{array}{l}\text { Zero- } \\
\text { order }\end{array}$ & Partial & Part & Tolerance & VIF \\
\hline \multirow[t]{3}{*}{1} & (Constant) & 2.338 & 1.471 & & & & & & \\
\hline & Profit & $-2.571 \mathrm{E}-06$ & .000 & -.375 & .651 & -.247 & -.154 & .168 & 5.960 \\
\hline & Size & .000 & .000 & 1.124 & .782 & .606 & .460 & .168 & 5.960 \\
\hline
\end{tabular}

a. Dependent Variable: CSR

Source: Authors' calculation

- Regression Tests

\section{Simultaneous Test (F test)}

To see if the independent variables simultaneously affect the dependent variable, the following hypotheses are set:

$H_{0}$ : Bank Size and Bank Profit do not have a simultaneous effect on CSR Reporting.

$H_{1}$ : Bank Size and Bank Profit have a simultaneous effect on CSR Reporting.

Table 7 ANOVA

\begin{tabular}{lllrrrr}
\hline \multirow{2}{*}{ Model } & $\begin{array}{c}\text { Sum of } \\
\text { Squares }\end{array}$ & df & Mean Square & F & Sig. \\
\hline \multirow{3}{*}{1} & Regression & 252.813 & 2 & 126.407 & 9.577 & $.004^{\mathrm{b}}$ \\
& Residual & 145.187 & 11 & 13.199 & & \\
\hline & Total & 398.000 & 13 & & & \\
\hline
\end{tabular}

a. Dependent Variable: CSR

b. Predictors: (Constant), Size, Profit

Source: Authors' calculation

As we can see, Table 7 - ANOVA shows the significance value of 0.004 which is < 0.05 so $\mathrm{H}_{0}$ is rejected, which means Bank Size and Bank Profit simultaneously affect the CSR Reporting. With this result, we can continue the regression further by testing the individual variables with t-tests. So, for the independent variable 'Bank Size', we set the following hypotheses:

$H_{0}$ : The size of a bank has no impact on the level of CSR reporting done by banks.

$H_{1}$ : The size of a bank has a positive impact on the level of CSR reporting done by banks. 
Table 8 Multiple regression

Coefficients

\begin{tabular}{|c|c|c|c|c|c|}
\hline \multirow[b]{2}{*}{ Model } & \multicolumn{2}{|c|}{ Unstandardized Coefficients } & \multirow{2}{*}{$\begin{array}{c}\text { Standardized } \\
\text { Coefficients }\end{array}$} & \multirow{2}{*}{$\mathrm{t}$} & \multirow{2}{*}{ Sig. } \\
\hline & $\mathrm{B}$ & Std. Error & & & \\
\hline $1 \quad$ (Constant) & 2.338 & 1.471 & & 1.589 & .140 \\
\hline Profit & $-2.571 \mathrm{E}-06$ & .000 & -.375 & -.844 & .417 \\
\hline Size & .000 & .000 & 1.124 & 2.529 & .028 \\
\hline
\end{tabular}

a. Dependent Variable: CSR

Source: Authors' calculation

Table 8 shows the results from Multiple Regression and it can be seen that the value of Bank Size variable significance is 0.028 which is $<0.05$ and hence, it can be concluded that $\mathrm{H}_{0}$ is rejected and $\mathrm{H}_{1}$ is accepted. This means that the size of the bank affects the CSR reporting, which means the bigger the banks are, the more they report for their CSR. Furthermore, we continue with the Profit variable and set the hypotheses:

$H_{0}$ : The bank's profitability has no impact on the level of CSR reporting done by banks. $H_{1}$ : The bank's profitability has a positive impact on the level of CSR reporting done by banks.

From the Table 8 for the Profit variable, it is noticed that the value of the significance is 0.417 which is greater than 0.05 , so in this case, we accept $\mathrm{H}_{0}$ and reject $\mathrm{H}_{1}$. This means that the profit or loss incurred by the bank does not affect their reporting of CSR.

Although it is logical to assume that the size of the realized profit is actually a larger amount of available funds that can be allocated by the banks for social responsibility and improvement of the society, while not disturbing their liquidity and survival, still the conducted statistical tests show that profits do not affect the level of CSR reporting in North Macedonia. This result can be explained by the characteristics of the population, habits, inertia of change, awareness of social responsibility etc. Social responsibility is increasingly found in the goals and policies of banks, which can be seen in their confidence that greater contribution and active participation in improving society will ensure better future results for all, especially for society and the financial results of banks, too. Changes can be expected in the near future as the population becomes more aware of the importance and significance of social responsibility, thus greater investment by banks in this field.

Finally, we will complete the analysis with the determination test. The purpose of this test is to see how the independent variable can explain the changes in the dependent variable.

Table 9 R Square

Model Summary

\begin{tabular}{|c|c|c|c|c|}
\hline Model & $\mathrm{R}$ & R Square & Adjusted R Square & $\begin{array}{l}\text { Std. Error of the } \\
\text { Estimate }\end{array}$ \\
\hline 1 & $.797^{\mathrm{a}}$ & .635 & .569 & 3.633 \\
\hline
\end{tabular}

R Square of the model is 0.635 which means that the Size and Profit of the banks explain as much as $63.5 \%$ of the CSR reporting by the banks in the Republic of North Macedonia. 


\section{RESEARCH LIMITATIONS}

CSR reporting is becoming increasingly important for companies on the one hand, as a means of attracting attention and proving their participation and status in society, but also for the general public as current or potential users of their services and current residents in the environment. The survey was conducted based on publicly disclosed information about their acts on social responsibility, for which other activities are likely to have been undertaken, but they were not highlighted or included in the report or part of CSR passage.

For the purpose of the survey, only secondary data collected from financial/annual reports or links and headings published on websites were used. No data were used from primary sources that would be collected through interviews and survey questionnaires. In the published information on CSR activities by the banks, there are no financial indicators or amounts that would make a better comparison and statistical tests, but only descriptive information which was then processed through the binary score to enable hypothesis testing. Apart from one of the large banks, there are no separate reports on social responsibility activities, so the data collection process was carried out through a detailed analysis of the financial and annual reports, as well as CSR links and headings published on the official websites. The COVID-19 pandemic is a current topic and period in which banks actively participate with their donations, support, deferred loan installments, etc., but, due to the time period of the research, the reports for 2020 have not been published yet, which would provide significant information and a comparative analysis of bank charities before and during the pandemic can be made, which is our recommendation for future research. It is also worth mentioning that there is not much research and published papers on corporate social responsibility in Macedonian practice, especially for the banking system.

\section{CONCLUSION}

Acting in a socially responsible manner is not only a moral behavior or philanthropy, but it is an essential part of the banks' strategies and long-term survival. Many international papers and surveys conducted by academic researchers, audit firms, and other regulatory bodies and stakeholders state that CSR reporting is increasingly and continuously becoming a field of social and public interest that makes pressure for greater regulation and transparency of corporate social impacts. On the other hand, by attracting high-quality employees, negotiating better contracts, expanding the customer base, attracting investors and gaining the trust of the public, addressing CSR is crucial to the profitability of the company. Among banks, being socially responsible is becoming a strategic goal and competitive advantage since their reputation depends on their CSR policies and programs.

The results obtained from the conducted content analysis show that ten banks $(71 \%)$ report on their philanthropy and voluntary participation in the betterment of society, while four banks (29\%) do not report on their social activities.

In the statistical analysis, two independent variables were used: the size and the profit of the banks, in order to determine whether they affect the CSR reporting. The conducted statistical tests show that the influence of the bank's profit is not significant. Conversely, the size of the bank has a very significant effect on CSR reporting. This shows that the size expressed through the total assets of the bank means larger available assets, more 
employees and more stakeholders, which increases their role, both, in the financial sector and from a social point of view.

However, the conclusions are based on publicly disclosed information and CSR reports, which does not exclude the possibility that there are additional social activities for which data are not available. There is a shortage and incentives are needed for banks to prepare individual reports on CSR activities.

\section{REFERENCES}

ACCA. (2015). Environmental accounting and reporting. Retrieved March 25, 2021 from: https://www.accaglobal. com/gb/en.404.html?/content/accaglobal/hk/en/student/exam-support-resources/professional-exams-study-resources/ p1/technical-articles/environmental-accounting-and-reporting.html

Achua, J. K. (2008). Corporate social responsibility in Nigerian banking system. Society and Business Review, 3(1), 57-71.

Adams, C., \& Ambika, Z. (2004). Corporate social responsibility: why business should act responsibly and be accountable. Australian Accounting Review, 14(34), 31-39.

Baird, P. L., Geylani, P. C., \& Roberts, J. A. (2012). Corporate Social and Financial Performance Re-Examined: Industry Effects in a Linear Mixed Model Analysis. Journal of Business Ethics, 109, 367-388.

Baseline study. (2007). Baseline study on CSR practices in the new EU member states and candidate countries. Retrieved April 1, 2021 from: http://www.cbcsr.mk/Upload/Content/Documents/BASELINE_STUDY_ON.pdf

Branco, M. C., \& Rodrigues, L. L. (2006). Corporate social responsibility and resource-based perspectives. Journal of business Ethics, 69(2), 111-132.

Carroll, A. B. (1979). A three-dimensional conceptual model of corporate performance. The Academy of Management Review, 4(4), 497-505.

Dorasamy, N. (2013). Corporate social responsibility and ethical banking for developing economies. Journal of Economics and Behavioral Studies, 5(11), 777-785.

Farooq, U. (2020). List The Importance Of Bank In Detail. Retrieved April 3, 2021, from Business Study Notes: https://www.businessstudynotes.com/others/banking-finance/discuss-importance-banks-detail/

Fatma, M., \& Rahman, Z. (2014). Building a corporate identity using corporate social responsibility: a website based study of Indian banks. Social Responsibility Journal, 10(4), 591-601.

Filipovska, M. (2019). Less is More Consolidation of the Macedonian Banking Market Improves Competition. Retrieved March 25, 2021 from: https://cms.law/en/mkd/publication/less-is-more-consolidation-of-themacedonian-banking-market-improves-competition

Garriga, E., \& Melé, D. (2004). Corporte Social Responsibility Theories: Mapping the Territory. Journal of Business Ethics, 53, 51-71.

GRI. (2002). Sustainability reporting guidelines. Boston: Global Reporting Initiative.

Hauser Institute for Civil Society. (2015). Corporate social responsibility disclosure efforts by national governments and stock exchanges. Retrieved March 28, 2021 from: http://hausercenter.org/iri/wp\%20content/uploads/2015/ 04/CSR-3-27-15.pdf

Hinson, R., Boateng, R., \& Madichie, N. (2010). Corporate social responsibility activity reportage on bank websites in Ghana. International Journal of Bank Marketing, 28(7), 498-518.

Jain, A., Keneley, M., \& Thomson, D. (2015). Voluntary CSR disclosure works! Evidence from Asia-Pacific banks. Social Responsibility Journal, 11(1), 2-18.

Jiang, C. L., Bazarova, N. N., \& Hancock, J. T. (2011). The disclosure-intimacy link in computer-mediated communication: An attributional extension of the hyperpersonal model. Human Communication Research, 37, 58-77.

Khan, H., Halabi, A., \& Samy, M. (2009). Corporate social responsibility (CSR) reporting: a study of selected banking companies in Bangladesh. Social Responsibility Journal, 5(3), 344-357.

Khan, H. Z. (2010). The Effect of Corporate Governance Elements on Corporate Social Responsibility (CSR) Reporting: Empirical Evidence from Private Commercial Banks of Bangladesh. International Journal of Law and Management, 52(2), 82-109.

Kılıç, M., \& Uyar, A. (2014). The impact of corporate characteristics on social responsibility and environmental disclosures in Turkish listed companies. In: Corporate Governance (pp. 253-276). Heidelberg, Berlin: Springer.

KPMG. (2011). KPMG International Survey of Corporate Responsibility Reporting 2011. Retrieved March 29 , 2021 from: https://assets.kpmg/content/dam/kpmg/pdf/2012/02/Corporate-responsiblity-reporting-2012-eng.pdf 
KPMG. (2013). The KPMG survey of corporate responsibility reporting 2013. Retrieved April 1, 2021 from: https://assets.kpmg/content/dam/kpmg/pdf/2015/08/kpmg-survey-of-corporate-responsibility-reporting2013.pdf

KPMG. (2015). Currents of change: The KPMG Survey on Corporate Responsibility Reporting 2015. Retrieved April 1, 2021 from: https://assets.kpmg/content/dam/kpmg/pdf/2016/02/kpmg-international-survey-of-corporateresponsibility-reporting-2015.pdf

KPMG. (2016). Corporate responsibility reporting in the Banking sector. Key findings from the KPMG Survey of Corporate Responsibility Reporting 2015. Retrieved April 1, 2021 from: https://assets.kpmg/content/dam/kpmg/ pdf/2016/07/corporate-responsibility-in-the-banking-sector.pdf

KPMG. (2020). The time has come. The KPMG Survey on Sustainability Reporting 2020. Retrieved April 2 , 2021 from: https://assets.kpmg/content/dam/kpmg/xx/pdf/2020/11/the-time-has-come.pdf

Levkov, N., \& Palamidovska-Sterjadovska, N. (2019). Corporate Social Responsibility Communication In Western Balkans Banking Industry: A Comparative Study. Management Research and Practice, 11(3), 18-30.

Lukasz, S., \& Justyna, F. (2019). CSR of Banks in Poland. In A. Długopolska-Mikonowicz, S. Przytuła, \& C. Stehr (Eds.), Corporate Social Responsibility in Poland. Springer, pp. 73-90.

Matuszak, Ł., Różańska, E., \& Macuda, M. (2019). The impact of corporate governance characteristics on banks' corporate social responsibility disclosure: Evidence from Poland. Journal of Accounting in Emerging Economies, 9(1), 75-102.

Molyneux, P., Schaeck, K., \& Zhou, T. M. (2014). Too systemically important to fail' in banking-Evidence from bank mergers and acquisitions. Journal of International Money and Finance, 49, 258-282.

Nyarku, K. M., \& Hinson, R. E. (2017). Corporate social responsibility reporting of banks operating in Ghana. African Journal of Business Ethics, 11(2), 19-36.

PwC (2013). The rise of corporate social responsibility. A tool for sustainable development in the Middle East. Retrieved March 27, 2021 from: https://www.strategyand.pwc.com/m1/en/reports/2013/the-rise-of-corporatesocial-responsibility.pdf

Rogošić, A. (2014). Corporate social responsibility reporting of the banks in Bosnia and Herzegovina, Croatia and Montenegro. Theoretical \& Applied Economics, 21(9), 71-82.

Scholtens, B. (2006). Finance as a driver of corporate social responsibility. Journal of Business Ethics, 68, 19-33.

Scholtens, B. (2009). Corporate social responsibility in the international banking industry. Journal of Business Ethics, 86(2), 159-175.

Schreck, P. (2013). Disclosure (CSR Reporting). In S. Idowu, N. Capaldi, L. Zu, \& A. Gupta (Eds.), Encyclopedia of Corporate Social Responsibility. Berlin: Springer.

Simms, J. (2002). Business: corporate social responsibility - you know it makes sense. Accountancy, 130(11), 48-50.

Stamenkova, J. (2011). CSR in Macedonia: Country Report. European Company Law, 8(2-3), 123-127.

Youmatter. (2020). CSR Or Sustainability Report: Definition, Meaning, Benefits \& Examples From Companies. Retrieved March 31, 2021, from Youmatter: https://youmatter.world/en/definition/definitions-csr-report-importantexamples/

\section{OBJAVLJIVANJE KORPORATIVNE SOCIJALNE ODGOVORNOSTI (CSR) BANAKA I NJIHOVA ULOGA U POBOLJŠANJU DRUŠTVA U REPUBLICI SEVERNOJ MAKEDONIJI}

Društveno odgovorno poslovanje (DOP) je od velike važnosti za kompanije i druge zainteresovane strane, što obavezuje kompanije da uspostave način upravljanja koji će istovremeno voditi računa o ekološkim, socijalnim i etičkim aspektima faktora. Ako je korporativna odgovornost vodeći faktor za kompanije, one mogu lako steći konkurentsku prednost u odnosu na druge. Ovaj rad istražuje kako banke u Republici Severnoj Makedoniji izveštavaju o DOP-u i u kom formatu izveštaja se objavljuju podaci o DOP-u. Istraživanje se zasniva na metodi analize sadržaja i statističke analize kako bi se utvrdilo da li veličina i profit banaka utiču na izveštavanje o DOP-u. Uzorak obuhvaćen istraživanjem je 14 banaka kojima je Narodna banka Republike Severne Makedonije odobrila rad. Rezultati ovog istraživanja pokazuju da veličina banaka pozitivno utiče na izveštavanje o DOP-u, dok s druge strane profit na to ne utiče.

Ključne reči: DOP, objavljivanje podataka, banke, Severna Makedonija 